\title{
Preparation, acceptability and quality evaluation of fermented fish product Mowa shidal prepared from the Mola carplet (Amblypharyngodon mola, Hamilton, 1822)
}

\author{
Bipul Kumar Kakati ${ }^{*}$, Armaan Ullah Muzaddadi ${ }^{2}$ and Umesh Ch. Goswami ${ }^{3}$ \\ ${ }^{1}$ Department of Fishery Engineering \& Technology, College of Fisheries, Assam Agricultural University, Raha, \\ Nagaon-782 103 (Assam), INDIA \\ ${ }^{2}$ ICAR-Central Institute of Post-Harvest Engineering and Technology (CIPHET), ICAR, PAU, Ludhiana (Punjab), \\ INDIA \\ ${ }^{3}$ Department of Zoology, Gauhati University, Guwahati-781 014 (Assam), INDIA \\ *Corresponding author. E-mail: bkkakati@gmail.com
}

Received: January 25, 2016; Revised received: June 24, 2016; Accepted: August 08, 2016

\begin{abstract}
Mowa shidal was prepared from sundried Amblypharyngodon mola by the traditional fermentation process at ambient temperature, maintaining all possible hygienic conditions. Biochemical, microbiological and sensory qualities at the different stages of fermentation of Mowa shidal was monitored. The product was perfectly matured after 120 days of fermentation showing the characteristic shidal smell and a moist and sticky surface. The fermentation process did not show any significant effect $(P>0.05)$ on the proximate composition. The product had a high nutritional quality. The protein and ash content of the sample were recorded to be $31.28-31.70 \%$ and $9.95-11.11 \%$, respectively and $\mathrm{pH}$ showed 5.8-6.5 in 180 days of fermentation. The physicochemical analysis revealed that the fermented product was of acceptable quality. The TPC of Mowa shidal was $5.86 \mathrm{log} \mathrm{cfu} / \mathrm{g}$ in the first month of fermentation and it reached $4.82 \mathrm{log} \mathrm{cfu} / \mathrm{g}$ after 120 days. The counts gradually decreased with the increasing duration of fermentation. Most of the isolate was found to be Staphylococcus aureus. After the second month of fermentation $S$. aureus reached $54 \%$ of total count and might play an important role in the fermentation process. Pathogenic bacteria like Salmonellaspp. and $E$. coliwere absent, which indicate good sanitary practice during processing. Thus, the good quality shidal can be produced from $A$. mola with a high nutritional quality and consumer acceptability.
\end{abstract}

Keywords: Acceptability, Amblypharyngodon mola, Fermentation, Mowa Shidal, Preparation, Quality evaluation

\section{INTRODUCTION}

Shidal is a salt-free fermented fish product indigenous to the North eastern part of India. The product has a high consumer acceptance and has contributed in many ways to the diet of the people of the region. Generally, this traditional fish product is prepared exclusively from small freshwater fish, Puntius spp. (primarily from Puntius sophore), subjecting to fermentation for four to five months. In northeast India, Shidal has been an important commodity and thus has important market value. The increasing consumption of Shidal, might have a very bad impact on the stock of Puntius spp., thus in fish biodiversity in the region. At present, Shidal is being produced using dried estuarine fish Setipinna phasa (Hamilton, 1822), and become popular among the consumers in the region, because of its low price (Majumdar, 2007). But, the availability of quality raw materials in sufficient quantity in time might be a problem for producers, as the raw materials come from outside states. Therefore, identification of a new local species, as raw material for preparation of
Shidal is need of the hour.

The northeastern part of India is endowed with large number of small indigenous fish species. Although these species are considered as weed fishes, it has high nutritional value (Karthikeyan et al., 2007). The availability of these species during winter period (December-January) is plenty from the region in general and during Katal/Jeng fishing in beels/wetlands in Assam in particular. During this time, the price of this small indigenous species fetch very less in the markets. Based on the availability and the biochemical composition of the fresh small indigenous fish species like Amblypharyngodon mola, Gudusia chapra, Colisa fasciata etc. studied (Karthikeyan et al., 2007), the mola carplet, A. mola (Hamilton, 1822), was selected for the preparation of Shidal in the present study. A. mola, locally known as Mowa, is popular among small indigenous fish species available in northeast India. A. mola belongs to the order cypriniformes, family cyprinidae and sub-family rasborinae. The species is distributed in India, Bangladesh, Pakistan, Myanmar and Afghanistan. It is abundantly available in the rivers, 
streams, beels, tanks and inundated fields.

The nutritive value of Shidal from Puntius spp. and Setipinna spp. has been reported to be high (Kakati and Goswami, 2013). The important factor which determines the value of a fish product is its biochemical composition and processing techniques often tends to affect the nutritional value of food products (Suchitra and Sarojnalini, 2012). Keeping all these points in mind, the present work dealt with the biochemical changes, microbial changes and sensory attributes of Shidal prepared from $A$. mola during fermentation. The work had relevance to human nutrition and health of the consumers and aims at the product nutritionally rich at the time retaining the acceptability and special flavour of choice.

\section{MATERIALS AND METHODS}

Mowa Shidal was prepared following the traditional method, maintaining all possible hygienic conditions during preparation process (Fig. 1). An in-process study was done at monthly intervals to record the biochemical, microbiological and sensory qualities at different stages of fermentation in six months. For the experiment, 8 sets of earthen pots (locally called as Koloh, which was round bottomed and narrow necked earthen vats, the capacity of which ranges from 10-40 $\mathrm{kg}$ ) were prepared. Sampling, in each Koloh was done in three strata such as top layer, middle layer and bottom layer. A Koloh, once opened was not used for further research to ensure equal and uniform anaerobic condition before opening.

\section{Standardized traditional method of Shidal preparation}

Preparation of raw materials: Fresh A. mola was collected of uniform size (average length $6.6 \mathrm{~cm}$ and average weight $5.25 \mathrm{gm}$ per fish) from natural resources as soon as they were harvested. Then the fishes were degutted and washed properly with good quality water to remove dirt and slime.

Drying: Dressed fishes were dried under sun for 4-5 days on raised bamboo platforms to reduce the moisture content. Care was taken for non infestation of fishes with insect pest during sun drying.

Oil processing: The inner and outer surface of the Koloh was smeared with mustard oil and allowed to sun dry. This process was continued for week, until the Koloh become saturated with oil and was unable to absorb any more oil even after fresh drying.

Soaking: Sun dried A. mola were soaked in potable water for 5-10 minutes depending on the texture of the fishes. After soaking, fishes were spread on the bamboo mat, and covered with a net overnight to drain out the water.

Packing: A Koloh was fixed (keeping underground up to the belly) tightly in the ground, keeping it upright or in a thermo-coal board tightly in vertical position. Now packing was done by spreading the fishes in layer inside the koloh and uniform pressure was applied with hand after wearing gloves. Once the layer gets tightly packed subsequent layers were put in a similar manner up to neck portion of koloh.

Sealing of Koloh: After packing of the koloh, the mouth portion (from the neck to rim of the Koloh) was covered with a cover paste. Then the cover paste is covered with a coverleaf (polythene) and kept in a shelter place undisturbed for 3-4 days. A layer of thick clay was applied on the paste after removing the cover leaf. Mending was done with another layer of clay when crack appear and it continued until no more crack appear on the seal.

Fermentation: The Koloh was kept undisturbed for 34 months at room temperature $\left(28 \pm 1^{\circ} \mathrm{C}\right)$. The ready Shidal was taken out from the Koloh after removing the mud and putrefied paste carefully.

Biochemical quality analysis: Moisture, crude protein, fat and ash content of Mowa Shidal were determined by AOAC methods (2000), standard methods were used for the determination of salt-soluble nitrogen (SSN; Dyer et al., 1950), non-protein nitrogen (NPN; AOAC, 2000), total volatile base nitrogen (TVB-N; Conway, 1947), peroxide value (PV; Jacobs, 1958), free fatty acids (FFA; Nambudiri, 1985). $\mathrm{pH}$ was determined using a $\mathrm{pH}$ meter (Sartorius make, Germany).

Microbiological and sensory quality analysis: The microbial quality of Mowa Shidal was determined by the methods of APHA (2001) and USFDA (2001). Mowa Shidal samples were used for periodical sensory evaluation at one month interval by an expert panel of 10 judges. The experts were selected from the regular Shidal eaters, who gave the scores for appearance, color, texture and odor, using a five-point scale (Mahanta and Muzaddadi, 2012). The overall acceptability was calculated by taking arithmetic average from the score sheet (Table 1). Loss of characteristics Shidal smell was considered to be the prime criterion for quality deterioration. The judges also gave a descriptive quality analysis after feeling, seeing and smelling the raw Mowa Shidal at different stages of fermentation.

Statistical analysis: The SPSS (2000) statistical package was used for analysis of the experimental results. The data were analyzed as per one-way analysis of variance to calculate the significance difference $(\mathrm{P}<0.05)$ among the means were compared using the Duncan's Multiple Range Test (Snedecor and Cochran, 1962).

\section{RESULTS AND DISCUSSION}

Mowa Shidal prepared by the traditional method was perfectly ripened after 120 days of fermentation (Table 2), with characteristic strong Shidal smell, moist and sticky surface, dark brownish colour, moderately soft texture and with shape of the fish intact. From the organoleptic point of view, the product after 120 days fermentation, showed best quality and the overall acceptability at this stage was 4.35 on a five-point scale 
Table 1.Quality scores for the sensory evaluation of Shidal (Mahanta and Muzaddadi, 2012).

\begin{tabular}{llcl}
\hline Quality attributes & Characteristics & Sensory scores & Quality \\
\hline Appearance & Bright, moist and shining surface & 5 & Excellent \\
& Slight dullness with shining surface & 4 & Good \\
& Dull with soft surface & 3 & Fair \\
& Definite dullness with soft surface & 2 & Average \\
& Dry fish like, loss of weight, fungal growth & 1 & poor \\
& Dark brownish or slight yellowish color & 5 & Good \\
Color & Gray yellowish or black color & 4 & Fair \\
& Pale brown or gray color & 3 & Average \\
& Color become fade and off-white & 2 & poor \\
& Whitish color & 1 & Excellent \\
Odor & Strong characteristics Shidal odor & 5 & Good \\
& Light characteristics Shidal odor & 4 & Fair \\
& Slight $S h i d a l$ odor with no sour odor & 3 & Average \\
& Faint sour odor & 2 & poor \\
Strong sour odor, rancid, ammonia smell & 1 & Excellent \\
& Firm elastic muscle, sticky surface and muscle not detached & 5 & Good \\
& from the backbone & & Fair \\
& Soft abdomen and fairly firm muscle & 4 & Average \\
& Muscle with no elasticity and firmness & 3 & poor \\
\hline
\end{tabular}

Table 2. Characteristics of Mowa Shidal in different stages of fermentation at room temperature $\left(28 \pm 1{ }^{0} \mathrm{C}\right)$.

\begin{tabular}{|c|c|c|}
\hline $\begin{array}{l}\text { Fermentation peri- } \\
\text { ods (days) }\end{array}$ & Characteristics of the products & Remarks \\
\hline 30 & $\begin{array}{l}\text { No characteristic Shidal smell, moist with moderately soft surface, hard } \\
\text { texture, almost no color change }\end{array}$ & Initiation of fermentation \\
\hline 60 & $\begin{array}{l}\text { Mild putrefied smell, Moist with moderately soft surface, moderately } \\
\text { hard texture, silvery, off-white color }\end{array}$ & $\begin{array}{l}\text { Fermentation activity } \\
\text { period }\end{array}$ \\
\hline 90 & $\begin{array}{l}\text { Shidal smell moderately prominent, moist with soft and sticky surface, } \\
\text { texture starts softening, color changes to pale brown }\end{array}$ & $\begin{array}{l}\text { Under- fermented, Pre- } \\
\text { ripened, low quality, but } \\
\text { acceptable }\end{array}$ \\
\hline 120 & $\begin{array}{l}\text { Characteristic strong Shidal smell, moist and sticky surface, dark } \\
\text { brownish color, moderately soft texture with shape of the fish intact }\end{array}$ & $\begin{array}{l}\text { Ripened, Best quality } \\
\text { Shidal }\end{array}$ \\
\hline 150 & $\begin{array}{l}\text { Characteristic strong Shidal smell prevails, moist with very soft surface, } \\
\text { texture very soft, shape of the fish distorted, color dark brown }\end{array}$ & $\begin{array}{l}\text { Over-fermented, post- } \\
\text { ripened, low quality, but } \\
\text { acceptable, }\end{array}$ \\
\hline 180 & $\begin{array}{l}\text { Characteristic strong Shidal smell no longer prevails, Moist with very } \\
\text { soft surface, the product almost turns to paste, color dark brown to black, } \\
\text { deterioration starts }\end{array}$ & $\begin{array}{l}\text { Degraded, over fer- } \\
\text { mented, poor quality }\end{array}$ \\
\hline
\end{tabular}

Table 3. Sensory quality of Mowa Shidal during fermentation.

\begin{tabular}{lcccccc}
\hline Parameters & \multicolumn{5}{c}{ Fermentation (days) } \\
\cline { 2 - 7 } N=10 & $\mathbf{3 0}$ & $\mathbf{6 0}$ & $\mathbf{9 0}$ & $\mathbf{1 2 0}$ & $\mathbf{1 5 0}$ & $\mathbf{1 8 0}$ \\
\hline Appearance & $3.20 \pm 0.30^{\mathrm{a}}$ & $3.50 \pm 0.20^{\mathrm{a}}$ & $3.80 \pm 0.10^{\mathrm{b}}$ & $4.20 \pm 0.10^{\mathrm{c}}$ & $3.60 \pm 0.30^{\mathrm{a}}$ & $3.30 \pm 0.30^{\mathrm{a}}$ \\
Color & $3.50 \pm 0.30^{\mathrm{a}}$ & $3.80 \pm 0.20^{\mathrm{ab}}$ & $4.20 \pm 0.20^{\mathrm{bc}}$ & $4.50 \pm 0.10^{\mathrm{c}}$ & $4.10 \pm 0.20^{\mathrm{b}}$ & $3.30 \pm 0.20^{\mathrm{a}}$ \\
Texture & $3.60 \pm 0.20^{\mathrm{b}}$ & $3.60 \pm 0.20^{\mathrm{b}}$ & $4.10 \pm 0.10^{\mathrm{c}}$ & $4.20 \pm 0.10^{\mathrm{c}}$ & $3.70 \pm 0.20^{\mathrm{b}}$ & $3.00 \pm 0.30^{\mathrm{a}}$ \\
Odor & $2.50 \pm 0.40^{\mathrm{a}}$ & $2.50 \pm 0.30^{\mathrm{a}}$ & $3.40 \pm 0.40^{\mathrm{b}}$ & $4.50 \pm 0.30^{\mathrm{c}}$ & $4.10 \pm 0.20^{\mathrm{bc}}$ & $3.50 \pm 0.20^{\mathrm{b}}$ \\
Overall acceptability & $3.20 \pm 0.20^{\mathrm{a}}$ & $3.35 \pm 0.20^{\mathrm{a}}$ & $3.88 \pm 0.15^{\mathrm{b}}$ & $4.35 \pm 0.15^{\mathrm{c}}$ & $3.88 \pm 0.20^{\mathrm{b}}$ & $3.28 \pm 0.30^{\mathrm{a}}$ \\
\hline
\end{tabular}

All values are means \pm standard deviations ; a-c means within a row, which are not followed by a common superscript letter (s) are significantly different $(\mathrm{P}<0.05)$.

(Tables 1, 3). However, the Shidal after fermentation of 90 days and 150 days were also acceptable though the judges recommended both the products as underfermented (pre-ripened) and over-fermented (postripened), respectively. The overall acceptability was 3.88 for both the stages, but, the quality was seen to be comparatively lower in respect of odour, texture and appearance. There was significant difference $(\mathrm{P}<0.05)$ in all the sensory quality parameters during fermentation period (Table 3). Voskresenky (1965) suggested that the rate of ripening depended on the quality, type of fish and temperature at which fermentation was taken place. 
Bipul Kumar Kakati et al. / J. Appl. \& Nat. Sci. 8 (3): 1534 - 1540 (2016)

Table 4. Biochemical quality evaluation of Mowa Shidal during fermentation at room temperature.

\begin{tabular}{|c|c|c|c|c|c|c|}
\hline \multirow{2}{*}{$\begin{array}{l}\text { Parameters } \\
\mathrm{N}=3\end{array}$} & \multicolumn{6}{|c|}{ Fermentation ( days) } \\
\hline & 30 & 60 & 90 & 120 & 150 & 180 \\
\hline$\%$ Moisture, & $39.36 \pm 1.05^{\mathrm{a}}$ & $39.31 \pm 0.76^{\mathrm{a}}$ & $39.26 \pm 0.21^{\mathrm{a}}$ & $39.21 \pm 1.23^{\mathrm{a}}$ & $39.23 \pm 0.96^{\mathrm{a}}$ & $39.28 \pm 0.88^{\mathrm{a}}$ \\
\hline $\begin{array}{l}\% \text { Crude pro- } \\
\text { tein, }\end{array}$ & $31.28 \pm 0.80^{\mathrm{a}}$ & $31.44 \pm 0.92^{\mathrm{a}}$ & $31.53 \pm 0.71^{\mathrm{a}}$ & $31.70 \pm 0.45^{\mathrm{a}}$ & $31.65 \pm 0.62^{\mathrm{a}}$ & $31.69 \pm 0.39^{\mathrm{a}}$ \\
\hline$\%$ Crude fat, & $17.65 \pm 1.10^{\mathrm{a}}$ & $17.70 \pm 1.00^{\mathrm{a}}$ & $17.83 \pm 1.05^{\mathrm{a}}$ & $17.98 \pm 0.76^{\mathrm{a}}$ & $17.89 \pm 0.68^{\mathrm{a}}$ & $17.91 \pm 0.87^{\mathrm{a}}$ \\
\hline$\%$ Ash, & $10.94 \pm 0.47^{\mathrm{a}}$ & $11.09 \pm 0.61^{\mathrm{a}}$ & $11.11 \pm 0.32^{\mathrm{a}}$ & $10.07 \pm 0.58^{\mathrm{a}}$ & $10.04 \pm 0.77^{\mathrm{a}}$ & $9.95 \pm 0.63^{\mathrm{a}}$ \\
\hline $\mathrm{pH}$ & $6.5 \pm 0.02^{\mathrm{d}}$ & $6.3 \pm 0.02^{c}$ & $6.0 \pm 0.10^{\mathrm{b}}$ & $5.8 \pm 0.02^{\mathrm{a}}$ & $5.9 \pm 0.01^{\mathrm{a}}$ & $6.1 \pm 0.02^{\mathrm{ab}}$ \\
\hline $\begin{array}{l}\mathrm{SSN},(\% \text { of } \\
\text { total } \mathrm{N})\end{array}$ & $49.5 \pm 0.54^{\mathrm{c}}$ & $48.7 \pm 0.47^{\mathrm{bc}}$ & $47.7 \pm 0.33^{\mathrm{b}}$ & $46.5 \pm 0.65^{\mathrm{b}}$ & $44.9 \pm 0.71^{\mathrm{a}}$ & $44.1 \pm 1.05^{\mathrm{a}}$ \\
\hline$\%$ NPN, & $2.05 \pm 0.19^{\mathrm{a}}$ & $2.08 \pm 0.28^{\mathrm{a}}$ & $2.15 \pm 0.42^{\mathrm{ab}}$ & $2.26 \pm 0.11^{\mathrm{ab}}$ & $2.32 \pm 0.15^{\mathrm{b}}$ & $2.47 \pm 0.18^{\mathrm{b}}$ \\
\hline TVB-N, mg\% & $107.30 \pm 0.41^{\mathrm{a}}$ & $122.25 \pm 0.22^{b}$ & $138.10 \pm 0.90^{\mathrm{c}}$ & $148.50 \pm 0.35^{\mathrm{d}}$ & $167.20 \pm 0.88^{\mathrm{e}}$ & $246.36 \pm 1.06^{\mathrm{f}}$ \\
\hline $\begin{array}{l}\mathrm{PV} \text { ( meq } \mathrm{O}_{2} / \\
\mathrm{kg} \text { of fat) }\end{array}$ & $21.46 \pm 0.21^{\mathrm{a}}$ & $22.15 \pm 0.36^{\mathrm{ab}}$ & $22.56 \pm 0.18^{\mathrm{ab}}$ & $23.05 \pm 0.22^{\mathrm{ab}}$ & $23.67 \pm 0.12^{\mathrm{b}}$ & $23.78 \pm 0.11^{\mathrm{b}}$ \\
\hline $\begin{array}{l}\text { FFA, (\% as } \\
\text { oleic acid) }\end{array}$ & $49.87 \pm 1.26^{\mathrm{a}}$ & $50.76 \pm 0.82^{\mathrm{a}}$ & $51.95 \pm 1.11^{\mathrm{a}}$ & $52.47 \pm 0.74^{\mathrm{ab}}$ & $54.36 \pm 0.90^{\mathrm{ab}}$ & $56.68 \pm 0.66^{\mathrm{b}}$ \\
\hline
\end{tabular}

All values are means \pm standard deviations; a-f means within a row, which are not followed by a common superscript letter (s) are significantly different $(\mathrm{P}<0.05)$.

Table 5. .Microbiological quality evaluation of Mowa Shidal during fermentation at room temperature.

\begin{tabular}{|c|c|c|c|c|c|c|}
\hline \multirow{2}{*}{$\begin{array}{l}\text { Parameters } \\
\mathrm{N}=3\end{array}$} & \multicolumn{6}{|c|}{ Fermentation ( days) } \\
\hline & 30 & 60 & 90 & 120 & 150 & 180 \\
\hline TPC $(\log \mathrm{cfu} / \mathrm{g})$ & $5.86 \pm 0.68^{b}$ & $5.61 \pm 0.60^{b}$ & $5.49 \pm 0.72^{b}$ & $4.82 \pm 0.48^{\mathrm{a}}$ & $4.65 \pm 1.05^{\mathrm{a}}$ & $4.57 \pm 0.69^{\mathrm{a}}$ \\
\hline $\begin{array}{l}\text { Yeast and mould (log } \\
\mathrm{cfu} / \mathrm{g} \text { ) }\end{array}$ & $\mathrm{ND}^{\mathrm{b}}$ & $1.20 \pm 0.30^{\mathrm{a}}$ & $1.04 \pm 0.47^{\mathrm{a}}$ & $1.00 \pm 0.30^{\mathrm{a}}$ & $<1$ & $1.00 \pm 0.00^{\mathrm{a}}$ \\
\hline $\begin{array}{l}\text { Staphylococcus aureus } \\
(\log \mathrm{cfu} / \mathrm{g})\end{array}$ & $3.08 \pm 0.79^{\mathrm{a}}$ & $5.32 \pm 1.48^{\mathrm{c}}$ & $5.23 \pm 0.58^{\mathrm{c}}$ & $4.50 \pm 0.30^{\mathrm{b}}$ & $4.25 \pm 0.70^{\mathrm{b}}$ & $4.04 \pm 0.54^{\mathrm{b}}$ \\
\hline $\begin{array}{l}\text { Escherichia coli }(\log \\
\mathrm{cfu} / \mathrm{g})\end{array}$ & Absent & Absent & Absent & Absent & Absent & Absent \\
\hline $\begin{array}{l}\text { Salmonella sp. (log } \\
\text { cfu /g) }\end{array}$ & Absent & Absent & Absent & Absent & Absent & Absent \\
\hline
\end{tabular}

All values are means \pm standard deviations; a-c means within a row, which are not followed by a common superscript letter (s) are significantly different $(\mathrm{P}<0.05)$.

At the same time, bacteria present in the product were considered to produce metabolites that contribute to flavour and odour in the fermented fish products due to the proteolytic and lipolytic activities (Mackie et al., 1971; Sands and Crisan, 1974). Their degradation process brings out certain characteristic flavour, which are essential for the quality of the final product. They assist in the breakdown of fish tissue as well as the development of aroma and flavour (Beddows, 1985).

However, there was not so much variation in the biochemical composition during different stages of fermentation. The moisture content of the products varied from $39.21 \%$ to $39.36 \%$ during 180 days of fermentation (Table 4).There was no significant differences $(\mathrm{P}>0.05)$ in moisture changes during fermentation period. This fluctuation could be attributed to their fat content. El-Sebahy and Metwalli (1988) noticed a reduction in moisture content during fermenting of Bowri fish muscles prepared from Mugil cephalus. The high moisture content of the product might be due to the soaking in water of sundried $A$. mola during processing of Shidal. The percentage of ash content in- creased insignificantly $(\mathrm{P}>0.05)$ from $10.94 \%$ to $11.11 \%$ during the initial stage, but a tendency towards stabilization occurred at 90 days of fermentation and then decreased to $9.95 \%$ at 180 days of fermentation (Table 4). The utilization of the whole fish, including bones and scale in the fermentation, increased the ash content in the sample. Scales were reported to contribute higher ash content (Quadrate-I- Khuda et al., 1964) and also rich in mineral. The lipid content also increased and it obtained the maximum value $(17.98 \%)$ at 120 days but remained almost unchanged at the later stage. There was no significant variation $(P>0.05)$ during fermentation period. This finding was similar with the finding of Ijong and Ohta (1995) in Bakasang- a fermented fish sauce prepared from small whole sardines (Sardinela spp. or Stolephorous spp.), in which the crude lipid of $14.17 \%$ was found. The crude protein content at the initial stage of fermentation $(30$ days) was $31.28 \%$ and increased slightly to $31.69 \%$ in 180 days of fermentation (Table 4). The increase in protein content can be attributed to microbial synthesis of proteins from metabolic intermediates during their 
Fresh A. mola of uniform size $(6.6 \mathrm{~cm} \& 5.25 \mathrm{gm})$ was collected

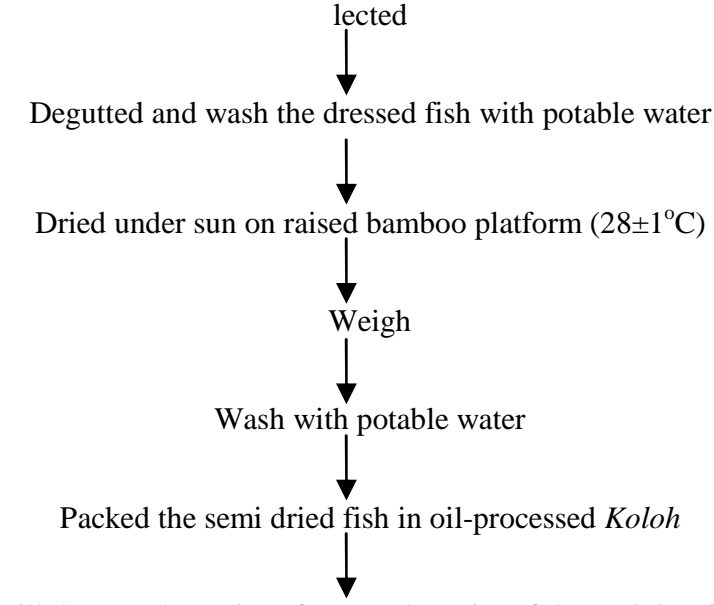

Fill the mouth portion (from neck to rim of the Koloh) with

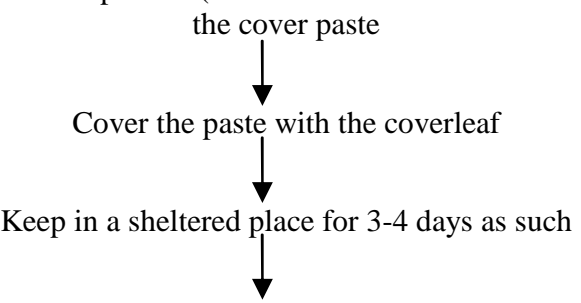

Apply a layer of thick clay on the paste after removing the coverleaf

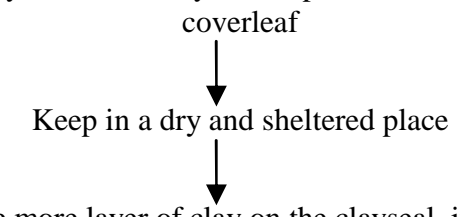

Apply one more layer of clay on the clayseal, if cracks appear on the seal

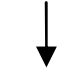

Repeat mending of cracks till no more cracks appear on the

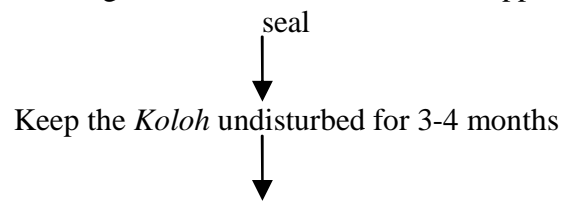

Remove the mud and putrefied paste carefully and take out the final product one layer after another

Fig. 1. The standardized traditional preparation of Mowa Shidal.

growth cycles. Protein might have been degraded to amino acids by the activities of fermenting microorganisms and used in the metabolic activities. Sanni et al. (2002) reported protein value of $16.8-21.9 \%$ in $M a-$ moni, a Ghanian fermented fish condiment prepared from various fish species. The result of the present experiment revealed that there was no significant effect of the fermentation process in the proximate composition of Mowa Shidal.

The $\mathrm{pH}$ changes of Mowa Shidal during 180 days of fermentation were recorded in the range of 5.8-6.6 and have significant difference $(\mathrm{P}<0.05)$ between different stages of fermentation. The $\mathrm{pH}$ value was decreased initially up to 120 days from 6.6 to 5.8 and then gradually increased to 6.1 in 180 days (Table 4). The increase in $\mathrm{pH}$ during the latter part of fermentation has been attributed to the formation of volatile basic compounds (Soyiri et al., 2003). The optimum $\mathrm{pH}$ for good quality Shidal prepared from Puntius spp. was recommended as 5.7 \pm 0.2 (Muzaddadi and Basu, 2012a).

The salt soluble nitrogen of Mowa Shidal as percentage of total nitrogen was found to be 49.5 and decreased significantly during fermentation period. The decreasing trend of SSN values might be attributed to denaturation of protein during fermentation. The NPN value of the present experiment increased significantly $(P<0.05)$ from $2.05 \%$ to $2.47 \%$ during fermentation of Mowa Shidal (Table 4). Non-protein nitrogen increased due to the utilization of the whole body of Puntius spp. in the fermentation process (Suchitra and Sarojnalini, 2012). This finding was supported by Oetterer et al., (2003) in which the treatment of enzymes present in the digestive system increased the NPN during fermentation. The increased value also attributed to the proteolytic activities of the fermenting microorganisms (Babu et al., 2005). The level of TVB-N doubled gradually as time elapsed and the range was 107.30 $\mathrm{mg} \%$ - $246.36 \mathrm{mg} \%$ during 180 days of fermentation. Significant variation $(\mathrm{P}<0.05)$ was observed between the stages of fermentation. It indicates the continuous production of volatile bases due to the breakdown of proteins by the action of microbes (Babu et al., 2005) and responsible for the generation of typical flavor and aroma of the final product (Majumdar et al., 2005). Bolzoni et al., (1996) also reported that the higher liberation of TVB-N was correlated with bacterial activity and biochemical changes in the fish muscles.

The PV and FFA values of the present experiment were found to be $21.46-23.78$ milliequivalent $\mathrm{O}_{2} / \mathrm{kg}$ of fat and $49.87-56.68 \%$ as oleic acid, respectively and increased significantly $(P<0.05)$ during the fermentation period (Table 4 ). As the fermentation of Shidal was an anaerobic or microaerophilic process, the PV and FFA values of Mowa Shidal were comparatively lower than the PV (39.12- 51.96 milliequivalent $\mathrm{O}_{2} / \mathrm{kg}$ of fat) and FFA value (64.5-74.6\% of oleic acid) recorded in the case of Puthi Shidal and Phassya Shidal collected from the markets during retailing (Kakati and Goswami, 2013).

Microbiological studies were carried out at one month intervals, for six months of fermentation (Table 5). Maximum fermentation occurred at 120 days, in terms of highest microbial activity combined with desirable $\mathrm{pH}$ and organoleptic changes (Tables 2-5). The TPC of Mowa Shidal was $5.86 \log \mathrm{cfu} / \mathrm{g}$ in the first month of fermentation and reduced to $5.49 \mathrm{log} \mathrm{cfu} / \mathrm{g}$ after 90 days and the counts gradually decreased with the increasing time of fermentation and lowered the total 
plate count to $4.57 \log \mathrm{cfu} / \mathrm{g}$ in 180 days. This showed that bacteria play a very important role in fish fermentation. Bacteria degraded fish protein, leading to the production of volatile compounds from amino acids and small peptides (Lopetcharat and Park, 2002).

Processing caused considerable changes in the composition of the microflora in counts as well as in the species found (Pivovarou et al., 1988). Most of the isolates were Staphylococcus aureus in the Mowa Shidal. In the third month of fermentation, $S$. aureus reached $54 \%$ of the total count (5.49 log cfu/g) and thereafter the count decreased in subsequent fermentation to 4.04 $\log \mathrm{cfu} / \mathrm{g}$ in 180 days. The presence of a large percentage of Staphylococcus aureus during the initial period and the end of the fermentation process of Mowa Shidal suggested $S$. aureus might play an active role during fermentation. The findings of Thapa et al. (2004) supported this finding, which showed the presence of S. aureus and Micrococcus spp. in the traditional fermented fish products of northeast India. Staphylococcus count exceeding $10^{6} / \mathrm{g}$ (or $6 \mathrm{log} \mathrm{cfu} / \mathrm{g}$ ) is considered to be hazardous (Bergdoll, 1979). In the present study, Staphylococcal count did not exceed $6 \mathrm{log} \mathrm{cfu} / \mathrm{g}$ and occurred within the acceptable limit (Table 5). During the six months of fermentation, yeast and mould count in Mowa Shidal declined slowly as the total population of fungi die. Anaerobic condition caused the declined of mould during the fermentation process (Chou et al., 1988). Sarojnalini and Vishwanath, (1988) observed many varieties of mould, from fish paste Hentak of Manipur. E. coli, which is an indicator of fecal pollution was not detected in the present experiment. It is a measure of the sanitary quality. Bacteria belonging to the genus Salmonella were not detected in the samples analyzed. As the Shidal was prepared from sun dried A. mola, they might be destroyed during sun drying $\left(28 \pm 1^{\circ} \mathrm{C}\right)$, as Salmonella is heat labile.

\section{Conclusion}

The study has revealed that good quality Shidal can be produced from A. mola with high nutritional quality and consumer acceptability. The sensory scores and descriptive analysis of Mowa Shidal during fermentation have suggested that the Shidal at 120 days of fermentation had the best overall quality. The results from the biochemical analysis revealed that the product had a high nutritive value as the protein, ash and fat content were observed to be high. The physicochemical qualities were found to be in acceptable limit. Though the count of $S$. aureus was high in the product, it was within the acceptable limit (6 log cfu/g) and there might be chance of having important role in fermentation process. The presence of small numbers of Staphylococcus in the product is not a serious problem but food poisoning may occur, if the product is handled carelessly during processing resulting in multipli- cation of the organism. In the entire experimental period, no pathogenic bacteria like Salmonella spp. and $E$. coli were observed indicating the good hygienic practice which was followed during the processing of Mowa Shidal. We concluded that A. mola might be a good candidate species for Shidal production and can minimize the pressure on over harvesting Puntius spp. As indigenous fermented fish have been and will continue to be an important fish food in bringing essential proteins to the consumers and as a vital part of the diet of Northeast India, these results will contribute a significant role in human nutrition.

\section{ACKNOWLEDGEMENTS}

Authors gratefully acknowledge the Shidal producers of Borduwa of Nagaon district of Assam, India for their unconditional help during preparation of Mowa Shidal.

\section{REFERENCES}

AOAC (2000). Official Methods of Analysis. $17^{\text {th }}$ ed. Association of Official Analytical Chemists, Washington, DC, USA.

APHA ( (2001). Compendium of Methods for the Microbiological Examination of foods. .. Frances, P. D. and keith, I. ( $4^{\text {th }}$ Ed.), American Public Health Association Inc., New York.

Babu, U.S.J., Rao, B.M., Khasim, D.I. and Nair, K.G.R. (2005). Biochemical and microbiological quality of formic acid silage and Lactobacillus fermented silage. Fish Technol. 42 (2): 163-170.

Beddows, C.G. (1985). Fermented fish and fish products: In: Microbiology of Fermented Food. Wood, B.J.B. (Ed.), Elsevier Science Publishing, New York. 2: 1-40.

Bergdoll, M.S. (1979). Foodborne Infections and Intoxication. Rieman, H. and Bryan, E. (Ed.) Academic Press, New York, USA, 444.

Bolzoni, L., Barbieri, G. and Virgili, R. (1996). Changes in volatile compounds of Parma ham during maturation. Meat Sci. 43: 301-310.

Chou, C.C., Hwang, G.R. and Frank Ming, H. (1988). Changes of microbial flora and enzyme activity during the aging of Tou-Pan-Chiang-a Chinese Fermented Condiment. J. Ferment. Technol. 66 (4): 472-478.

Conway, E.J. (1947). Micro-Diffusion Analysis and Volumetric Error. Crosby, Lockwood \& Sons, London.

Dyer, W.J., French, H.V. and Snow, J.M. (1950). Proteins in fish muscle, extraction of protein fraction in flesh. $J$. Fish Res. Bd. Con. 7: 585-593.

El-Sebahy, L.A. and Metwalli, M.S. (1988). Changes in some chemical characteristics and lipid composition of salted fermented Bouri fish muscle (Mugil cephalus). Food Chem. 31: 41-50.

Ijong, F.G. and Ohta, Y. (1995). Amino acids compositions of Baksang- a traditional fermented fish sauce from Indonesia. LWT-Food Sci. Technol. 28 (2): 236-237.

Jacobs, M.B. (1958). The chemical analysis of foods and food products. Krieger Publishing Co. Inc, New York, USA, pp 393-394.

Kakati, B.K. and Goswami, U.C. (2013). Characteristic of the traditional fermented fish product Shidol of northeast India prepared from Puntius sophore and Setipinna 
phasa. Indian J. Tradit. Knowle. 12 (1): 85-90.

Karthikeyan, M., Dhar, B., Mandal, D. and Kakati, B.K. (2007). Proximate composition and biochemical quality of small indigenous fish species of northeast India. $J$. Food Sci. Tech. 44 (1): 36-39.

Lopetcharat, K. and Park, J.W. (2002). Characteristics of fish sauce made from Pacific whiting and surimi by products during fermentation stage. J. Food Sci. 67: 511-516.

Mackie, I.M., Hardy, R. and Hobbs, G. (1971). Fermented fish products. FAO, Rome.

Mahanta, P. and Muzaddadi, A.U. (2012). Post-fermentation preservation of Shidal- a fermented fish product of northeast India, Fish Technol. 49 (2): 177-186.

Majumdar, R.K. (2007). Phassya Shidal- A traditional fermented fish product of NE India, Fishing Chimes. 27 (5): 30-31.

Majumdar, R.K., Basu, S. and Anandan, R. (2005). Biochemical and microbiological characteristics of salt fermented Hilsa (Tenualosa ilisha). Fish Technol., 42 (1): 67-70.

Muzaddadi, A.U. and Basu, S. (2012). Shidal- a traditional fishery product of Northeast India. Indian J. Tradit. Knowle. 11(2): 323-328.

Muzaddadi, A.U. and Basu, S. (2012). An accelerated process for fermented fish (Seedal) production in Northeast region of India. Indian J. Animal Sci. 82 (1): 98-106.

Nambudiri, D.D. (1985). Analytical Manual of Fish and Fishery Products. Directorate of Extension, Kerala Agric. University, Kerala, India.

Oetterer, M., Sergio, D.P., Claudio, R.G., Lia Ferraz de Arruda, Ricaddo, B. and Ana, M., Paschoal Da C. (2003). Monitoring the sardine (Sardinella brasiliensis) fermentation process to obtain anchovies, Scientia. Agricola. 60 (3): 511-517.

Pivovarov, Y.P., Linevich, L.S., Grachaeva, M.M., Podyasenev, S.V. and Sazonova, L.P. (1988). Microflora of meat fish products. Gigiena I, E.
Sanitariya. No. 8:18-21.

Quadrate-I- Khuda, M., Rahaman, K.M. and Khan, N.A. (1964). Fish and Fish Products. part 4, Evaluation of certain important types of fish for their valuable constituents and essential amino acids. Scientific Research East Reg. Lab., PC, CSIR Dacca, 1:49-56.

Sands, A. and Crisan, E.V. 1974. Microflora of fermented Korean seafoods. J. Food Sci. 39: 1002-1005.

Sanni, A.I., Asiedu, M. and Ayernor, G,S. (2002). Microflora and chemical composition of Momoni, a Ghanaian fermented fish condiment. J. Food Comp. Anal. 15: 577-583.

Sarojnalini, C. and Vishwanath, W.S. (1988). Composition and digestibility of fermented fish foods of Manipur. $J$. Food Sci. Technol. 35: 349-351.

Snedecor, G.W. and Cochran, W.G. (1967). Statistical methods. Oxford and IBH publishing Co. Calcutta, pp. 339380.

Soriyi, I.N., Tano, D.K. and Amao, A.W.A. (2003). Physicochemical and quality characteristics of fish sauce produced from tuna processing wastes. 2nd International workshop on Food- based approaches for a healthy nutrition, pp. 683-696.

SPSS (2000). Statistical Package for Social Sciences for Windows. Release 10. Chicago, IL. SPSS Inc.

Suchitra, T. and Sarojnalini, Ch. (2012). Effect of temperature on biochemical and microbiological qualities of Ngari. Nature and Sci. 10 (2): 32-40.

Thapa, N., Pal, J. and Tamang, J.P. (2004). Microbial diversity in Ngari, Hentak and Tungtap, fermented fish products of Northeast India. World J. Microbiol. Biotechnol. 20 (6): 599-607.

USFDA (2001). Bacteriological Analytical Manual, $8^{\text {th }}$ Edn. (Revised) Association of Official Analytical Chemists, Washington DC.

Voskresensky, N.A. (1965). Salting of herring. In: Fish as Food. Vol. 3, Processing Part 1, Borgstrom, G., (Ed.) Academic Press, New York, London, pp. 107-128. 